\title{
A Systematic Review: How are Mental Model of Chemistry Concepts?
}

\author{
Annisa Chiyarotul Wardah ${ }^{1}$, Antuni Wiyarsi²,* \\ ${ }^{1}$ Department of Chemistry Education, Graduate Programme, Yogyakarta State University, Indonesia \\ ${ }^{2}$ Department of Chemistry Education, Faculty of Mathematics and Natural Science, Yogyakarta State University, Indonesia
}

Received September 26, 2019; Revised December 25, 2019 Accepted December 27, 2019

Copyright $\odot 2020$ by authors, all rights reserved. Authors agree that this article remains permanently open access under the terms of the Creative Commons Attribution License 4.0 International License

\begin{abstract}
This descriptive content analysis study was carried out to review students and pre-service teachers' mental model of chemistry concepts. This study was motivated by difficulties experienced by students and teachers in the process of learning chemistry. This study put on criteria with specific keyword about a mental model in chemistry concepts and a period of 2009 till 2019 which relevant databases yielded a total of 66 articles. This study covers 41 qualitative studies, 18 quantitative studies, and this remains mix method studies. Article's aspects focused on such parameters as aim, method, sample, data collection tool, data analysis, chemistry concept, mental model theory, and recommendation of studies. Using content analysis, as a result was known that most studies used qualitative methods with a variety of data collection tools and data analysis techniques. Moreover, these mental models studies were mostly involved students who learned inorganic chemistry. General conclusions from this study in the importance form of the mental model exploration to master the chemistry concepts and this is intended to improve the chemistry learning process. This research also implies to do good innovative changes in various aspects to improve their scientific mental model. These changes include to innovate classroom practices, further researches, curriculum policy, and learning media developer.
\end{abstract}

Keywords Content Analysis, Chemistry Concepts, Mental Model

\section{Introduction}

Chemistry is an abstract and complex subject Johnstone [1]. The results of several studies showed that complex and abstract chemical facts make learning and teaching of chemistry difficult for students and teachers [2-4], so Sirhan[5] stated that it is hard to understand the chemistry concepts.

Understanding the concept of chemistry can be realized through several representational abilities byKozma \& Rusell[6], which includes a) representing chemistry phenomena at various levels; b) predicting the nature of chemicals and their movement processes; c) identifying and analyzing representational features using words; d) distinguishing representations that can explain something in common but through different ways; e) connecting different representations to map features of one representation; f) understanding that the representation is in accordance with observed phenomenon; and g) using representations and features as evidence to support claims, draw conclusions, and make predictions related to observed phenomena. However, in fact, the result by $[7,8]$ indicated that not all of these abilities are owned by students, because mastery of chemical representations is not easy.

At present, Gilbert \& Treagust[9] revealed that scientists emphasize the understanding of three levels in chemical representations, namely the macroscopic, symbolic, and submicroscopic levels. However, in reality, so far the process of learning chemistry has not been presented with all three levels of representation simultaneously, but only limited to the symbolic level, whereas macroscopic representations tend to be ignored $[10,11]$.

Based on Jansoon, Coll, and Somsook[12], understanding of the three levels of chemical representations is often known as a mental model. Grosslight, Unger, Jay, and Smith[13] added that all three are interrelated and reflect the development of the mental model. In general, the mental model is understood as structural, behavioral, or functional analogs of objects, processes, events, or real or imaginary situations. Gentner[14] expected mental models support understanding, reasoning, and prediction of situations in which they are involved from logical reasoning in everyday situations to solve some problems in the 
knowledge domain. Johnson-Laird[15] suggested a mental model theory that relies on three basic principles. First, each mental model represents what is common to a different set of possibilities. Second, mental model is icon, namely structure related to what they represent. Third, mental model based on descriptions represents what is right at the expense of what is wrong.

The development of students' mental model cannot be separated from the teachers' roles. As suggested by Nahum, Hofstein, Mamlok-Naaman, and Bar-Dov[16], teachers must facilitate the development of students' mental model, while ensuring that students do not develop false mental models, so that students' understanding of the material concept can be improved. In addition, Bodner and Domin[17] said that it is necessary to develop students' mental models through experiences, interpretation, and explanations to make predictions, test new ideas, and solve problems in chemistry learning. Therefore, this research is needed to determine the extent of collaboration between teachers and students in developing mental models to solve chemical problems.

\section{Objectives}

This research aimed to thematically review the mental model study in chemistry concepts from 2009 to 2019 . The following eight questions guided this research:

1. What were the aims of the mental model in chemistry concept studies?

2. What methods did these studies use?

3. Who were the samples involved in these studies?

4. What data collection tools did these studies use?

5. What data analysis techniques did these studies apply?

6. What chemistry concepts did these studies focus on?

7. Which mental model theories that are referred to in these studies?

8. Which recommendations did these studies offer?

\section{Methods}

\subsection{The Research Design}

Descriptive content analysis was done to find studies conducted on participants' mental model in chemistry concepts. This mental model explains how participants represent a chemistry concept, through verbal, drawings, diagrams, maps, and so on.

\subsection{Data Collection}

As the research aim was to review students and pre-service teachers' mental model of chemistry concepts, so this research used purposive sampling to find articles, there were 66 articles found. These articles were obtained through several databases like Research Gate, Google
Scholar, Crossref, and Library Genesis with keywords of the mental model in chemistry, chemistry concept understanding, and chemical representation. The articles selected which discuss the mental models of participants about certain chemistry concepts in the range of articles published from 2009 to 2019 . Initially, there were 100 articles that appeared in those databases with the keywords, but after being analyzed there were 34 articles that did not include the criteria.

Based on these reviews, the 66 obtained articles consisted of 41 qualitative studies, 18 quantitative studies, and 7 mixed-method studies. These participants involved in that studies were not only students but also pre-service teachers and teachers in chemistry and science field. The students include high school and university students.

\subsection{Data Analysis}

In this study, a literature review was carried out which contained conceptual and empirical literature approvals based on certain criteria. The review was conducted by studying using themes that appear in the articles analyzed. Like the previous content analysis studies conducted by $[18,19]$.

Initially, great attention was given to the abstracts of each study in order to generate common themes in this research. After looking at the abstracts, then the most attention was paid to the results of each study. The results of the study was conceptualized, listed and grouped by themes to draw a general picture of what the current study says about the mental model in chemistry concept. The identified common themes were presented and discussed individually below.

\section{Results}

\subsection{Result of Aim Theme}

Frequencies of the aim theme via the codes are presented in Table 1.

As presented in Table 1, the aim theme consisted of five different codes. The first code, exploring the mental model profile of chemistry concept(s) has the highest number. Most of the research aims to describe how to represent a chemistry concept. They classified profiles of mental model based on the several experts' theory. The factors that contribute to mental model shaping were also examined as well. In the 14 studies, they explain argumentation skill, multiple representations competence, teaching strategy, and thinking ability factors were $3,7,1$, and 3 respectively. It is true that mental model is closely related to misconceptions. Therefore, about three researches have been carried out to investigate the relationship between the misconception of the chemistry concept(s) and mental models. Unfortunately, there was still limited research that looks at the consistency mental model in chemistry. 
Table 1. Frequencies of Aim Theme in the Mental Model Studies

\begin{tabular}{|c|c|c|}
\hline Theme & Codes & $\mathrm{f}$ \\
\hline \multirow{5}{*}{ Aim } & Explore the mental model profile of chemistry concept(s) & 46 \\
\hline & $\begin{array}{l}\text { Investigate the factor(s) that contributed to mental model shaping (argumentation skill, multiple representations } \\
\text { competence, teaching strategy, thinking ability) }\end{array}$ & 14 \\
\hline & Investigate the relationship between misconception of the chemistry concept(s) and mental models & 3 \\
\hline & Investigate how chemistry concept(s) are related to difficulties in mental models & 2 \\
\hline & Explain the consistency of mental models & 1 \\
\hline Total & & 66 \\
\hline
\end{tabular}

Table 2. Frequencies of Method Theme in the Mental Model Studies

\begin{tabular}{|c|c|c|c|}
\hline Theme & \multicolumn{2}{|r|}{ Codes } & \multirow{2}{*}{$\frac{\mathrm{f}}{5}$} \\
\hline \multirow{16}{*}{ Method } & \multirow{9}{*}{ Qualitative } & Qualitative descriptive & \\
\hline & & Case study & 4 \\
\hline & & Interpretive study & 4 \\
\hline & & Phenomenographic study & 3 \\
\hline & & Content analysis & 2 \\
\hline & & Cross-sectional study & 2 \\
\hline & & Explorative study & 2 \\
\hline & & Longitudinal study & 1 \\
\hline & & Other (Qualitative, but the design is not specified) & 19 \\
\hline & & Experimental & 7 \\
\hline & Ou: & Quantitative descriptive & 3 \\
\hline & 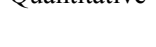 & Survey & 3 \\
\hline & & Other (Quantitative, but the design is not specified) & 3 \\
\hline & Mixed- & Explanatory Sequential & 1 \\
\hline & method & Other (Mixed-method, but the design is not specified) & 6 \\
\hline & & $\mathrm{R} \& \mathrm{D}$ & 1 \\
\hline & & & 66 \\
\hline
\end{tabular}

\subsection{Result of0 Method Theme}

Frequencies of the method theme via the codes are displayed in Table 2.

Based on Table 2, it can be seen at the end of the last ten years, the type of dominant mental model research carried out in a qualitative method. In this study, there were 42 qualitative studies analyzed. They were 5 descriptive studies, 4 case studies, 4 interpretive studies, 3 phenomenographic studies, 2 content analysis, 2 cross-sectional studies, 2 explorative studies, and one for a longitudinal study. Besides them, there were 19 qualitative designs not determined. Besides being used in qualitative method, descriptive studies can also be done through quantitative method. In this study there were 3 quantitative descriptive studies analyzed. In general, quantitative research on mental models which analyzed in this study used experimental methods were 7 studies. Furthermore, there were 3 quantitative mental model studies which not specifically mentioned about the design, 3 survey studies, and only one research and development study respectively. From a total of 66 mental model studies analyzed, there were only 6 mix-method studies with non-explicit designs and one explanatory sequential study.

\subsection{Result of Sample Theme}

Frequencies of the sample theme via the codes can be seen in Table 3.

Table 3. Frequencies of Sample Theme in the Mental Model Studies

\begin{tabular}{|c|c|c|c|}
\hline Theme & \multicolumn{2}{|c|}{ Codes } & $\mathrm{f}$ \\
\hline \multirow{8}{*}{ Sample } & \multirow{3}{*}{ Student(s) } & University & 17 \\
\hline & & High school & 22 \\
\hline & & Middle school & 4 \\
\hline & \multirow{2}{*}{ Pre-service teacher(s) } & Chemistry & 14 \\
\hline & & Science & 5 \\
\hline & \multicolumn{2}{|c|}{ Chemistry teacher(s) } & 5 \\
\hline & \multicolumn{2}{|c|}{ Textbook(s) } & 2 \\
\hline & \multicolumn{2}{|c|}{ Data(s) } & 1 \\
\hline \multicolumn{3}{|c|}{ Total } & 70 \\
\hline
\end{tabular}


As presented in Table 3, frequencies of the sample theme in the mental model studies were 43 for students consisting university students, high school students, and middle school students were 17,22 , and 4 respectively. In addition, pre-service teachers were also involved in these mental model studies. There were 14 pre-service chemistry teachers and 5 pre-service science teachers. Other samples were 5 chemistry teachers, 2 textbooks, and data.

\subsection{Result of Data Collection Tool Theme}

Frequencies of the data collection tool theme via the codes are presented in Table 4.

Table 4. Frequencies of Data Collection Tool Theme in the Mental Model Studies

\begin{tabular}{|c|c|c|}
\hline Theme & Codes & $\mathrm{f}$ \\
\hline \multirow{15}{*}{$\begin{array}{c}\text { Data Collection } \\
\text { Tool }\end{array}$} & Interview protocol(s) & 30 \\
\hline & Open-ended question(s) & 23 \\
\hline & Diagnostic test(s) & 12 \\
\hline & Questionnaire(s) & 10 \\
\hline & Drawing test(s) & 8 \\
\hline & Multiple-choice question(s) & 6 \\
\hline & Audio-video recording(s) & 4 \\
\hline & Alternativetive summaries tool(s) & 3 \\
\hline & Rubric(s) & 3 \\
\hline & Textbook(s) & 3 \\
\hline & Worksheet(s) & 2 \\
\hline & Card & 1 \\
\hline & Observation sheet & 1 \\
\hline & Scale & 1 \\
\hline & Written text & 1 \\
\hline \multicolumn{2}{|r|}{ Total } & 108 \\
\hline
\end{tabular}

As seen in Table 4, the data collection tool theme consisted of fifteen different codes. They are 30 interview protocols, 23 open-ended question sets, 12 diagnostic tests, 10 questionnaires, 8 drawing tests, 6 sets of a multiple-choice question, 4 audio-video recordings, 3 for alternative summaries tools, rubrics, and textbook respectively. In addition, 2 worksheets and then only one for card, observation sheet, scale, and written text respectively.

\subsection{Result of Data Analysis Theme}

Frequencies of the data analysis theme via the codes are performed in Table 5 .

Based on Table 5, it can be seen at the end of last ten years, the most of mental model studies used qualitative data analysis, where coding analysis is most widely conducted and subsequent descriptive analysis. In addition, another qualitative data analyzes used were 4 for content analysis, 3 for constant-comparative technique, 3 for inductive analysis, and 2 for phenomenographic analysis. Furthermore, there were quantitative data analysis techniques which include t-test, descriptive statistics, Wilcoxon test, ANOVA, and inferential statistics have 6, 4, 3, 2, and 2 respectively. And then, only one article which used ANCOVA, Fisher's exact test, Kruskal Wallis Test, LCA (Latent Class Analysis), MANOVA, Pearson correlation, Regression, and Two-tailed analysis.

Table 5. Frequencies of Data Analysis Theme in the Mental Model Studies

\begin{tabular}{|c|c|c|c|}
\hline Theme & \multicolumn{2}{|r|}{ Codes } & $\mathrm{f}$ \\
\hline \multirow{20}{*}{$\begin{array}{c}\text { Data } \\
\text { Analysis }\end{array}$} & \multirow{6}{*}{ Qualitative } & Coding & 25 \\
\hline & & Descriptive analysis & 13 \\
\hline & & Content analysis & 4 \\
\hline & & $\begin{array}{c}\text { Constant-comparative } \\
\text { technique }\end{array}$ & 3 \\
\hline & & Inductive analysis & 3 \\
\hline & & Phenomenographic analysis & 2 \\
\hline & \multirow{13}{*}{ Quantitative } & T-test & 6 \\
\hline & & Descriptive statistics & 4 \\
\hline & & Wilcoxon test & 3 \\
\hline & & ANOVA & 2 \\
\hline & & Inferential statistics & 2 \\
\hline & & ANCOVA & 1 \\
\hline & & Fisher's exact test & 1 \\
\hline & & Kruskal Wallis Test & 1 \\
\hline & & $\begin{array}{c}\text { LCA } \\
\text { (Latent Class Analysis) }\end{array}$ & 1 \\
\hline & & MANOVA & 1 \\
\hline & & Regression & 1 \\
\hline & & Pearson correlation & 1 \\
\hline & & Two-tailed & 1 \\
\hline & \multicolumn{2}{|c|}{ Alternative scoring keys } & 13 \\
\hline \multicolumn{3}{|c|}{ Total } & 88 \\
\hline
\end{tabular}

\subsection{Result of Chemistry Concept Theme}

Frequencies of the chemistry concept theme via the codes can be seen in Table 6 .

As displayed in Table 6, the chemistry concept theme consisted of six different codes. They included 31 inorganic, 19 physical, 6 analytical, 5 organic, 3 environmental, and 2 basic chemistry concepts. Each code consists of more detailed chemistry concepts which can be seen in Table 6. 
Table 6. Frequencies of Chemistry ConceptTheme in the Mental Model Studies

\begin{tabular}{|c|c|c|c|}
\hline Theme & & Codes & $\mathrm{f}$ \\
\hline \multirow{24}{*}{$\begin{array}{l}\text { Chemistry } \\
\text { concept }\end{array}$} & \multirow{5}{*}{$\begin{array}{l}\text { Inorganic } \\
\text { chemistry }\end{array}$} & Atomic structure & 15 \\
\hline & & Chemical bonding & 11 \\
\hline & & Molecular modeling & 2 \\
\hline & & Hybridization & 1 \\
\hline & & Quantization & 1 \\
\hline & \multirow{11}{*}{$\begin{array}{l}\text { Physical } \\
\text { chemistry }\end{array}$} & Rate of reaction & 6 \\
\hline & & $\begin{array}{l}\text { Properties and behavior } \\
\text { of gases }\end{array}$ & 3 \\
\hline & & Chemical reactions & 2 \\
\hline & & Basic quantum chemistry & 1 \\
\hline & & $\begin{array}{c}\text { Chemical and physical } \\
\text { properties }\end{array}$ & 1 \\
\hline & & Colligative properties & 1 \\
\hline & & Compton effect & 1 \\
\hline & & Diffusion & 1 \\
\hline & & Electrochemistry & 1 \\
\hline & & Geometry and polarity & 1 \\
\hline & & Stoichiometry & 1 \\
\hline & \multirow{3}{*}{$\begin{array}{l}\text { Analytical } \\
\text { chemistry }\end{array}$} & Acids base & 3 \\
\hline & & $\begin{array}{c}\text { Matter, evaporation, } \\
\text { combustion, dissolution, } \\
\text { phase change }\end{array}$ & 2 \\
\hline & & Dilution & 1 \\
\hline & \multicolumn{2}{|c|}{ Organic chemistry } & 5 \\
\hline & \multirow{3}{*}{$\begin{array}{l}\text { Environmenta } \\
1 \text { chemistry }\end{array}$} & Chemistry phenomena & 1 \\
\hline & & Geological Hazards & 1 \\
\hline & & $\begin{array}{l}\text { The emergent nature of } \\
\text { chemical entities }\end{array}$ & 1 \\
\hline & \multicolumn{2}{|c|}{ Basic chemistry } & 1 \\
\hline \multicolumn{3}{|c|}{ Total } & 66 \\
\hline
\end{tabular}

\subsection{Result of Mental Model Theory Theme}

Frequencies of the mental model theory theme via the codes are displayed in Table 7.

Based on Table 7 , it can be seen that 7 of the mental model studies focused on Johnson-Laird [15] theory, whereas 3 of them concentrated on Grosslight, Unger, Jay, and Smith[13] and Johnstone[2] respectively. Also, there were mental model theory from [20-22] were 2, 2, and 2 respectively. In addition, respectively only 1 study that concerned on [23-30] mental model theory. Furthermore, there were 27 other mental model theories used.
Table 7. Frequencies of Mental Model TheoryTheme in the Mental Model Studies

\begin{tabular}{|c|c|c|}
\hline Theme & Codes & $\mathrm{f}$ \\
\hline \multirow{16}{*}{$\begin{array}{l}\text { Mental } \\
\text { Model } \\
\text { Theory }\end{array}$} & Johnson-Laird (1983) & 7 \\
\hline & Grosslight, Unger, Jay, and Smith (1991) & 3 \\
\hline & Johnstone (1991) & 3 \\
\hline & Kozma and Russell (1997) & 2 \\
\hline & Park and Light (2009) & 2 \\
\hline & Sendur, Toprak, and Pekmez (2010) & 2 \\
\hline & Chittleborough (2004) & 1 \\
\hline & diSessa (2004) & 1 \\
\hline & Gilbert and Watts (1983) & 1 \\
\hline & Mayer (2003) & 1 \\
\hline & Park and White (2007) & 1 \\
\hline & Taber (1994) & 1 \\
\hline & Talanquer (2006) & 1 \\
\hline & Wang (2011) & 1 \\
\hline & Other & 27 \\
\hline & Not applicable & 12 \\
\hline Total & & 66 \\
\hline
\end{tabular}

\subsection{Result of Recommendation Theme}

Frequencies of the recommendation theme via the codes can be seen in Table 8 .

Table 8. Frequencies of Recommendation Theme in the Mental Model Studies

\begin{tabular}{|c|c|c|}
\hline Theme & Codes & f \\
\hline \multirow{4}{*}{ Recommendation } & $\begin{array}{c}\text { Implications to do innovative } \\
\text { classroom practices }\end{array}$ & 27 \\
\cline { 2 - 3 } & $\begin{array}{c}\text { Implications to do further } \\
\text { researches }\end{array}$ & 19 \\
\cline { 2 - 3 } & $\begin{array}{c}\text { Implications to improve } \\
\text { curriculum policy }\end{array}$ & 4 \\
\cline { 2 - 3 } & $\begin{array}{c}\text { Implication for learning media } \\
\text { developer }\end{array}$ & 2 \\
\cline { 2 - 3 } & Not applicable & 66 \\
\hline
\end{tabular}

As presented in Table 8, 27 of the mental model studies recommended doing innovative classroom practices whilst 19 of them suggested to do further researches and 4 studies implied to improve curriculum policy. Furthermore, there were 7 studies implied for practitioners. 


\section{Discussion}

The results of our analysis are presented in this section which discusses the research questions that guide the study (see Table 1). Firstly, given the first research question of the mental model studies that the most aim code in studies analyzed is 'Explore the mental model profile of chemistry concept(s)'. This shows that many studies have explored the shape of participants' mental models in understanding chemistry concepts. This is in line with the Lin, Chiu, and Liang [31]which said that exploration of mental models is very important to do. During this time, various ways of exploring mental models in chemistry have been done, for example Park and Light[32] explored the troublesome nature of atomic structure from three students' perspective, drawing on their own experience and understanding of the concept. This exploration is conducted deeply through interviews. Mental models were classified based on scientific models and level of understanding. The result of this study showed that it turned out that many alternative models of atomic structure are owned by the three students. Hence, Park \& White [32] described that how to teach and how to learn about chemistry concept is an important issue in chemistry education.

The second most aim code is 'Investigate the factors that contributed to mental model shaping'. Based on the results of these studies analyzed, they have found some factors that contribute in mental model shaping, such as argumentation skill [33-35], multiple representation competences [36-41], teaching strategies by Kırık and Boz[42], and thinking ability[43-45]. For argumentation skill factor, Calik and Kolomuc[33] suggested that combining different conceptual change methods such as argumentation with the teaching intervention could help students overcome alternative conceptions for chemistry concepts and that students were able to store their new knowledge in their long-term memories. This suggestion is line with the opinion from [46,47] who stated that argumentation is a fundamental discourse of science, a part of the practice of science for developing, evaluating, and refining, scientific theories about the natural world. For multiple representation competences factor, Hilton and Nichols [38] presented that the development of an understanding of the form of individual multiple representation competences is an important step in helping chemistry students interpret them. Unfortunately, there were still many students who have low mastery of these competencies [36,37,39,48,49]. For teaching strategies factor, Kırık and Boz[42] summarized that contributing to the progress of science learning is difficult. Students-centered methods which provide students with the ability to construct their own knowledge require more efforts than teacher-centered methods. However, teaching strategies are actively involved in their learning process to promote meaningful learning and motivation. For thinking ability factor, Flavell[50] stated that an act of thinking about one's own mental process plays important role in reading and oral comprehension, writing, and problem solving in science. Furthermore, Wang, Haertel, and Walberg [51]described that thinking ability is the most powerful predictor of learning. As a result statements from [43-45] indicated the importance of thinking ability issues to students' knowledge organization and it influences the development of mental model.

The next aim code is 'Investigate the relationship between misconception of the chemistry concept(s) and mental models'. It is undeniable that mental models are closely related to misconceptions, many studies linked both [52-54]. This is reinforced by the opinion of Griffiths and Preston [55] who claimed that students' misconceptions may result from formal instruction and the interaction between teachers and students. For instance, inappropriate teaching strategies and teachers' own misconceptions may result in students' misconceptions [56,57]. In addition, researchers mentioned some problematic representations shown in textbooks. For instance, curriculum designers usually use concrete scientific models for explaining abstract concepts. The way they use may make students only learn the models we presented but not the concepts themselves $[58,59]$. From these theories, it can be concluded that misconceptions are very impactful toward the mental model.

One difficulty in developing the mental model of a concept is mastery of that concept [12-13]. Like the results of the research conducted by [60-61] who stated that the students still have difficulty understanding chemistry concepts, even teachers had trouble specifying students' difficulties in understanding. From the analysis of these studies, the next aim code obtained is 'Investigate how chemistry concept(s) are related to difficulties in mental models'.

In addition, of the 66 studies that have been analyzed, there is only one study that examined the consistency of mental model in mastering the chemistry concept which is conducted by Zarkadis, Papageorgiou, and Stamovlasis[62]. Kwen[63] confirmed, by consistency means the common application of conceptualization or framework to explain a number of related contexts, thus, from an educational point of view demonstrating a conceptual understanding of underlying scientific ideas. The results of the study discussed in terms of between and within consistency, whereas the conclusions contribute to the debate concerning the coherent vs. fragmented knowledge hypotheses. The empirical evidence provided by the analysis clearly demonstrates that student mental models for chemistry concepts, especially for the atomic structure were not coherent when applying in different everyday situations. From the analysis of this study, the last aim code obtained is 'Explain the consistency of mental models'.

The fact is that the mental model studies frequently 
used qualitative methods (see Table 2), because these methods may be regarded as more appropriate to explore the mental model, especially in chemistry concepts. Furthermore, a close numerical relationship between quantitative and qualitative research designs may result from their research which aims to investigate the mental model development with different interventions, for example the most frequently used design was experimental. Few mental model studies which used mix methods, it is possible because of many requirements and workloads, from data collection process which must use several tools and data analysis process which need in-depth analysis and data triangulation technique. Also, the lowest number of the mental model studies is R \& D method which may not be right to explore mental model. Unfortunately, from 66 studies there were still many studies that did not explain the design explicitly, so it cannot be known clearly about the spread of the design of each study.

The next fact is the most mental model studies involved students, both high school and university students (see Table 3). This is caused by the relationship between university students who will later be involved in the chemistry teaching process in high school. But, it seems this is not right on target sample because the university students involved were not chemistry educational program students. There is no mistake of involving them, but it will be better if more studies are involved chemistry educational program students as samples because they are pre-service teachers who will be directly involved in chemistry learning in the school. All of these because of the mental model development cannot be separated from the teacher's role. As suggested by Nahum, Hofstein, Mamlok-Naaman, and Bar-Dov[16], teachers have to facilitate the students' mental model development and ensure that students do not develop unscientific mental model, so that students' understanding of chemistry concepts can be improved.

As presented in Table 4, the mental model studies mostly exploited with interview protocols and open-ended questions. Most of the interview protocols in qualitative research, because it may become the right tool for collecting data in mental model studies. From the interview process, the participants can represent chemistry concepts verbally. Each interview process is usually accompanied by an audio-video recording process. In addition, many open-ended questions have been used for mental model researches. From these tools, participants can get answers that are illustrated through drawings, diagrams, maps, and another. Besides using questions with open types, mental models were also explored through questions in multiple-choices and diagnostic tests form. Then, there were other data collection tools which were used several times in mental model researches, including questionnaire, drawing test, rubric, observation sheet, worksheet, scale, card, written text, textbooks, and another alternative summaries tool. All data collection tools mentioned above, each has advantages and disadvantages, therefore there were many mental model types of researches that used multiple data collection tool in one study, this is intended to enrich the data.

The highest frequency of the mental model studies is used qualitative data analysis (see Table 5), especially coding analysis. This is in accordance with many studies that aimed to explore mental models and then classify them through the coding process. Based on the coding results that have been obtained, then a lot of research continues the process of data analysis through the description process. This description process turns out to be able to use qualitative techniques, it can also be done through quantitative, namely through descriptive statistics. However, from 88 data analysis techniques that have been presented, there were only 27 quantitative data analysis techniques that were spread evenly through the t-test, Wilcoxon test, ANOVA, ANCOVA, MANOVA, Regression, Kruskal Wallis Test, LCA (Latent Class Analysis), Fisher's exact test, Two-tailed, Pearson correlation, and inferential statistics. The rest, other mental model studies were chosen alternative scoring keys techniques to process the data that have been obtained. All data analysis techniques carried out must have been adapted to the data collection tools used and the forms of data obtained. For example, only one study that used LCA (Latent Class Analysis) technique to analyze the consistency of atomic structure mental model Zarkadis, Papageorgiou, andStamovlasis[62]. Because of this LCA technique is the most effective clustering method to concern the consistency of knowledge and mental model, comprise the categorization of certain mental models on the basis of their patterns of responses [64-66].

Most frequency of mental model studies examined inorganic chemistry concepts. From 66 studies, there were 31 studies discussed them. The most inorganic chemistry concepts studied was atomic structure concept. Park, Light, Swarat, and Denise [21] had reasons why they took atomic structure concept, because the atom is a threshold concept in science and its concepts are abstract, so the way to teach and learn about the atomic theory must be well considered. The next most chemistry concept studied by Taber and Coll[67] was chemical bonding, because chemical bonding is one of the most important topics taught in chemistry at high school level and this topic is dominated by the use of models. In addition, study by Özmen [68] understanding bonding in chemistry is particularly important since further learning relies heavily upon it. Such as research conducted by Vladušić, Bucat, and Ožić[69] choose the concept of chemical bonding because students were vulnerable to using alternative concepts in representing this concept. The third most chemistry concept studied was the rate of reaction. Some studies gave the reasons that there were some problems have been reported when teaching students about the rate 
of reaction concepts $[34,70,71]$. In addition, the rate of reaction has abstract concept, but according to Wiyarsi, Sutrisno and Rohaeti[72], the abstractness of chemistry concept can be represented through multiple representation levels, i.e. macroscopic, microscopic, symbolic, and mathematics.

The mental model studies under investigation mostly encouraged by Johnson-Laird[15] mental model theory (see Table 7). Based on that theory, the mental model has important role used to understand the underlying source of misconceptions and learners' reasoning patterns. Therefore, many mental model studies have been analyzed aimed to investigate the relationship between misconception of the chemistry concepts and mental models. When constructing mental model of a system, an individual creates mental entities that represent perceived or conceived entities of the system and establishes their properties, relationships, behaviors or functions. Johnstone[2] added even more that when describing chemistry phenomena, chemists generally present concepts at three levels of knowledge representation: the macroscopic, sub-microscopic, and symbolic levels. Hence, there were some mental model studies that intended to investigate the factors that contributed to mental model shaping, especially in multiple representations competences.

The most mental model studies recommended several implications to do innovative classroom practices and to do further researches. These recommendations were submitted because the researches that have done hope that there will be improvements for further research. In addition, given that learning activities in the classroom are directly related to the mental model shaping, innovation is needed. In this case, the role of teachers and students, curriculum, learning media are needed. On curriculum policy improvement, proper policies are needed from curriculum formers. In achieving this goal, they make collaboration with the teachers and students, because the subject of the curriculum and they are directly involved in the impact of curriculum implementation. Likewise in learning media innovation is also needed practitioners like expert developers who are professional in technology developing and mastering the chemistry concepts.

\section{Conclusions}

A total of 66 academic mental models in chemistry studies consisting of articles which published in national and international journals were investigated with regard to their aims, methods, samples, data collection tool, data analysis tools, chemistry concepts, mental model theories, and recommendations of the studies. The result of this research is that qualitative studies with the various design were adopted more in these studies. These studies were also enriched with the role of the sample involved diverse.
In addition, the diversity of the data collection tools and data analysis techniques can increase our knowledge in world research. From the mental model studies analyzed that have been done, we know that it turned out that all chemistry concepts can be examined by mental models and of course these studies were supported by various mental model theoretical from various experts. All of the diversity of these studies was carried out to various aims achievement well.

\section{Recommendations}

Provided general knowledge claims of the mental model in chemistry studies, this research implies the following recommendations:

1. The perspectives of mental model studies which specifically discussing consistency are still limited. In addition, exploration needs to be conducted to maintain the consistency of scientific mental models, especially in chemistry concepts.

2. During this time, most mental model studies have been carried out using qualitative methods. This is logic because the mental model is delivered descriptively. Qualitative methods that often done were content analysis and descriptive but actually content analysis is better because there is in-depth coding while descriptive is only explained. For further research, if the researcher wants to explain the chemistry concept mental model more in-depth then it is recommended to use content analysis design. In addition, there is no harm if further research is done by combining quantitative research in it so that the type of mixed-method more applicable.

3. To date, the dominant sample involved in mental model studies is students, especially non-educational chemistry university students. As a suggestion, the mental model studies involving educational chemistry students should be multiplied. Because they will be facilitators and influence directly on students' mental model development in chemistry learning.

4. Various mental model data collection tools have been used. This can be an inspiration for further research to use several data collection tools at the same time in one study, in order to obtain more comprehensive findings.

5. Accuracy is needed in analyzing mental model research data because each type of research has data analysis techniques that are exactly done. This is objected to making the data which have been obtained can be handled properly.

6. Indeed there have been many chemistry concepts that have been studied by mental model, but all concepts in chemistry needed to be registered so that 
mental model studies of those concepts can be carried out.

7. So far, mental model studies have only used old mental model theories. Therefore, renewal of mental model theory is needed, especially in chemistry education.

8. One of the characteristics of good research is research that recommends something for a good future. Based on the mental model studies that have been analyzed, there are still an amount of studies that have not implicated this. Therefore, this is a concern for further research.

\section{Acknowledgements}

The authors would like to thank all researchers who have studied mental model in the chemistry field so that it becomes a great reference for our research. Thanks a lot to you all reviewers for suggestions and feedback.

\section{Appendix}

\section{A List of Studies Reviewed}

1. S. M. Al-Balushi. Factors influencing pre-service science teachers' imagination at the microscopic level in chemistry, International Journal of Science and Mathematics Education, Vol.7, 1089-1110. 2009.

2. E. J. Park, G. Light. Identifying atomic structure as a threshold concept: Student mental models and troublesomeness, International Journal of Science Education, Vol.31, No.2, 233-258, 2009.

3. K. Adbo, K. S. Taber. Learners' mental models of the particle nature of matter: A study of 16 - year old Swedish science students, International Journal of Science Education, Vol.31, No.6, 757-786, 2009.

4. C. Stefani, G. Tsaparlis. Students' levels of explanations, models, and misconceptions in basic quantum chemistry: A phenomenographic study, Journal of Research in Science Teaching, Vol.46, No.5, 520-536, 2009.

5. N. Jansoon, R. K. Coll, E. Somsook. Understanding mental models of dilution in thai students, International Journal of Environmental \& Science Education, Vol.4, No.2, 147-168, 2009.

6. B. Venkataraman. Visualization and interactivity in the teaching of chemistry to science and non-science students, Chemistry Education Research and Practice, Vol.10, 62-69, 2009.

7. R. G. Yayla, G. Eyceyurt. Mental models of pre-service science teachers about basic concepts in chemistry. Western Anatolia Journal of Education Science, 285-294, 2010.
8. Ö. Taştan, E. Yalçinkaya. Pre-service chemistry teachers' ideas about reaction mechanism, Journal of Turkish Science Education, Vol.7, No.1, 47-60, 2010.

9. M. Calik, A. Kolomuc, Z. Karagolge. The effect of conceptual change pedagogy on students' conceptions of rate of reaction, Journal of Science Education and Technology, Vol.19, 422-433, 2010.

10. J-W. Lin, M-H. Chiu. The Mismatch between students' mental models of acids/bases and their sources and their teacher's anticipations thereof, International Journal of Science Education, Vol.32, No.12, 1417-1644, 2010.

11. A. M. Strickland, A. Kraft, G. Bhattacharyya. What happens when representations fail to represent? Graduate students' mental models of organic chemistry diagrams, Chemistry Education Research and Practice, Vol.11, 293-301, 2010.

12. C. Y. Wang, L. H. Barrow. Characteristics and levels of sophistication: an analysis of chemistry students' ability to think with mental, Research Science Education, Vol.41, 561-586, 2010.

13. A. Kolomuç, S. Tekin. Chemistry teachers' misconceptions concerning concept of chemical reaction rate, Eurasian Journal of Physics and Chemistry Education, Vol.3, No.2, 84-101, 2011.

14. L. McClary, V. Talanquer. College chemistry students' mental models of acids and acid strength, Journal of Research in Science Teaching, Vol.48, No.4, 396-413, 2011.

15. B. Bektaşli, G. Çakmakci. Consistency of students' ideas about the concept of rate across different contexts, Education and Science, Vol.36, No.162, 273-287, 2011.

16. M. Tuysuz, B. Ekiz, O. Bektas, E. Uzuntiryaki, A. Tarkin, E. S. Kutucu. Pre-service chemistry teachers' understanding of phase changes and dissolution at macroscopic, symbolic, and microscopic levels, Procedia - Social and Behavioral Sciences, Vol.15, 452-455, 2011.

17. A. Hilton, K. Nichols. Representational classroom practices that contribute to students' conceptual and representational understanding of chemical bonding, International Journal of Science Education, Vol.33, No.16, 2215-2246, 2011.

18. S. P. Madden, L. L. Jones, J. Rahm. The role of multiple representations in the understanding of ideal gas problems, Chemistry Education Research and Practice, Vol.12, 283-293, 2011.

19. A. Kolomuç, M. Çalık. A Comparison of chemistry teachers' and grade 11 students' alternative conceptions of 'rate of reaction', Journal of Baltic Science Education, Vol.11, No.4, 333-346, 2012.

20. M. Aydeniz, A. Pabuccu, P. S. Cetin, E. Kaya. Argumentation and students' conceptual understanding of properties and behaviors of gases, 
Journal of New Horizons In Education, Vol.10, 1303-1324, 2012.

21. O. T. Kırı, Y. Boz. Cooperative learning instruction for conceptual change in the concepts of chemical kinetics, Chemistry Education Research and Practice, Vol.13, 221-236, 2012.

22. D. A. D. Lajium. Students' mental model of chemical reactions, Research Science Education, Vol.41, 561-586, 2012.

23. P. C. C. Mendonc, R. Justi. An instrument for analyzing arguments produced in modeling-based chemistry lessons, Journal of Research in Science Teaching, Vol.51, No.2, 192-218, 2013.

24. M. Hegarty, M. Stieff, B. L. Dixon. Cognitive change in mental models with experience in the domain of organic chemistry, Journal of Chemical Education, Vol.25, No.2, 220-228, 2013.

25. N. D. A. Halim, M. B. Ali, N. Yahaya, M. N. H. M. Said. Mental model in learning chemical bonding: A preliminary study, Social and Behavioral Sciences, Vol.97, 224-228, 2013.

26. A. Bergqvist, M. Drechsler, O. D. Jongb, S. C. Rundgren. Representations of chemical bonding models in school textbooks - help or hindrance for understanding? Chemistry Education Research and Practice, Vol.14, No.4, 589-606, 2013.

27. R. Vladušić, A. B. Bucat, M. Ožić. Understanding ionic bonding - A scan across the Croatian education system, Chemistry Education Research and Practice, Vol.20, No.2, 1-14, 2013.

28. H. Tümay. Prospective chemistry teachers' mental models of vapor pressure, Chemistry Education Research and Practice, Vol.15, No.3, 366-379, 2014.

29. A. Bouayad, F. Kaddari, M. Lachkar, A. Elachqar. Quantum model of chemical bonding: Barriers and learning difficulties, Social and Behavioral Sciences, Vol.116, No.2, 4612-4616, 2014.

30. M. Stains, H. Sevian. Uncovering implicit assumptions: a large-scale study on students' mental models of diffusion, Research Science Education, 1-34, 2014.

31. J. Joki, J. Lavonen, K. Juuti, M. Aksel. Coulombic interaction in Finnish middle school chemistry: a systemic perspective on students' conceptual structure of chemical bonding, Chemistry Education Research and Practice, Vol.16, No.4, 901-917, 2015.

32. S. Supasorn. Grade 12 students' conceptual understanding and mental models of galvanic cells before and after learning by using small-scale experiments in conjunction with a model kit, Chemistry Education Research and Practice, Vol.6, No.2, 393-407, 2015.

33. Sunyono. Introductory study on student's mental models in understanding the concept of atomic structure (Case study on High School students in
Lampung Indonesia), Journal of New Horizons in Education, Vol.5, No.4, 41-50, 2015.

34. Sunyono, L. Yuanita, M. Ibrahim. Mental models of students on stoichiometry concept in learning by method based on multiple representation, Journal of New Horizons in Education, Vol.5, No.2, 30-45, 2015.

35. R. S. DeFever, H. Bruce, G. Bhattacharyya. Mental rolodexing: Senior chemistry majors' understanding of chemical and physical properties, Journal of Chemical Education, Vol.92, No.3, 415-426, 2015.

36. S. Mulyani, Liliasari, Wiji. Model mental calon guru kimia mengenai sifat koligatif larutan melalui pembelajaran berbasis TIK, Jurnal Pendidikan Matematika dan Sains, Vol.3, No.2, 123-132, 2015.

37. I. W. Suja. Model mental mahasiswa calon guru kimia dalam memahami bahan kajian stereokimia, Jurnal Pendidikan Indonesia, Vol.4, No.2, 623-636, 2015.

38. I. W. Suja, F. Nurlita. Persepsi dan model mental mahasiswa tahun pertama terhadap pembelajaran kimia organik di SMA, Seminar Nasional Riset Inovatif, Vol.4, 355-361, 2016.

39. O. Ozcan, C. Gercek. Students' mental models of light to explain the compton effect, Social and Behavioral Sciences, Vol.191, No.6, 2195-2197, 2015.

40. G. Papageorgiou, A. Markos, N. Zarkadis. Students' representations of the atomic structure - the effect of some individual differences in particular task contexts, Journal of Chemical Education. Vol.17, No.1, 209-219, 2016.

41. L. Sunyono, Yuanita, M. Ibrahim. Supporting students in learning with multiple representation to improve student mental models on atomic structure concepts, Science Education International, Vol.26, No.2, 104-125, 2015.

42. E. Çil, M. Uğraş. The concept of hybridization from the perspective of science teaching undergraduate students: A phenomenographic study, Journal of Baltic Science Education, Vol.14, No.2, 227-236, 2015.

43. S. C. Chen, M. S. Hsiao, H. C. She. The effects of static versus dynamic 3D representations on 10th grade students' atomic orbital mental model construction: Evidence from eye movement behaviors, Computer in Human Behavior, Vol.53, 169-180, 2015.

44. S. Akaygun. Is the oxygen atom static or dynamic? The effect of generating animations on students' mental models of atomic structure, Chemical Education Research and Practice, Vol.17, No.4, 788-807, 2016.

45. H. Tümay. Reconsidering learning difficulties and misconceptions in chemistry: Emergence in chemistry and its implications for chemical 
education, Chemistry Education Research and Practice, Vol.53, 1-15, 2016.

46. N. D. Körhasan, L. Wang. Students' mental models of atomic spectra, Chemistry Education Research and Practice, Vol.20, No.2, 1-5, 2016.

47. S. A. Kiray. The pre-service science teachers' mental models for concept of atoms and learning difficulties, International Journal of Education in Mathematics, Science and Technology, Vol.4, No.2, 147-162, 2016.

48. A. Bergqvist, M. Drechsler, S-N. C. Rundgren. Upper secondary teachers' knowledge for teaching chemical bonding models, International Journal of Science Education, Vol.38, No.2, 298-318, 2016.

49. M. L. Head, K. Yoder, E. Genton, J. Sumperl. A quantitative method to determine preservice chemistry teachers' perceptions of chemical representations, Chemical Education Research and Practice, 1-18, 2017.

50. A. Majid, B. K. Prahani. Analyze of students' learning outcomes based on mental, IOSR Journal of Research \& Method in Education, Vol.7, 120-124, 2017.

51. A. Pabuccu, S. Erduran. Beyond rote learning in organic chemistry: The infusion and impact of argumentation in tertiary education, International Journal of Science Education, Vol.39, No.9, 1154-1172, 2017.

52. S. Moutinho, R. Moura, C. Vasconcelos. Contributions of model-based learning to the restructuring of graduation students' mental models on natural hazards, Applied Science and Technology, Vol.13, No.7, 3043-3068, 2017.

53. M. M. W. Cheng, J. K. Gilbert. Modelling students' visualisation of chemical reaction, International Journal of Science Education, Vol.39, No.9, 1173-1193, 2017.

54. S. Sarawan, C. Yuenyong. Thai students' mental model of chemical bonding, International Conference for Science Educators and Teachers, 1-7, 2017.

55. N. Zarkadis, G. Papageorgiou, D. Stamovlasis. Studying the consistency between and within the student mental models for the atomic structure, Chemistry Education Research and Practice, Vol. 26, No.4, 893-902, 2017.

56. M. A. Tichert, L. T. Tien, L. Dysleski, D. Rickey. Thinking processes associated with undergraduate chemistry students' success at applying a molecular-level model in a new context, Journal of Chemical Education, Vol. 94, No.9, 1195-1208. 2017.

57. R. Hanson. Unearthing conceptions about types of chemical bonding through the use of tiered worksheets, International Journal for Cross-Disciplinary Subjects in Education, Vol.8, No.2, 3112-3122, 2017.
58. J. Ealy. Analysis of students' missed organic chemistry quiz questions that stress the importance of prior general chemistry knowledge, Education Science, Vol.8, No.42, 1-13, 2018.

59. M. Slapničar, V. Tompa, S. A. Glažar, I. Devetak. Fourteen-year-old students' misconceptions regarding the sub-micro and symbolic levels of specific chemistry concepts, Journal of Baltic Science Education, Vol.17, No.4, 620-632, 2018.

60. Sunyono, Sudjarwo. Mental models of atomic structure concepts of 11 th grade chemistry students, Asia-Pacific Forum on Science Learning and Teaching, Vol.19, No.1, 1-21, 2018.

61. A. Majid, Suyono. Misconception analysis based on students mental model in atom structure materials, Advances in Engineering Research, Vol.171, 244-247, 2018.

62. U. J. Enero, R. Umesh. Representations of chemistry phenomena in secondary school chemistry textbooks, Chemistry Education Research and Practice, Vol.20, No.1, 146-159, 2018.

63. F. R. Amalia, S. B. Ibnu, R. Widarti, H. Wuni. Students' mental models of acid and base concepts taught using the cognitive apprenticeship learning model, Jurnal Pendidikan IPA Indonesia, Vol.7, No.2, 187-192, 2018.

64. N. D. Körhasan, A. Eryılmaz, Ş. Erkoç. The role of metacognition in students' mental models of the quantization, Science Education International, Vol.29, No.3, 183-191, 2018.

65. P. Meela, C. Yuenyong. The study of grade 7 mental model about properties of gas in science learning through model based inquiry, International Conference for Science Educators and Teachers, 1-6, 2018.

66. A. R. Zohar, S. T. Levy. Students' reasoning about chemical bonding: The lacuna of repulsion, Journal of Research and Science Technology, Vol.56, No.7, 1-24, 2019.

\section{REFERENCES}

[1] A. H. Johnstone. Teaching of chemistry-logical or psychological? Chemistry Education Research Practice, Vol.1, No.1, 9-15, 2000.

[2] A. H. Johnstone. Why is science difficult to learn? Things are seldom what they seem, Journal of Computer Assisted Learning, Vol.7, No.2, 75-83, 1991.

[3] A. H. Johnstone. The development of chemistry teaching: A changing response to changing demand, Symposium on Revolution and Evaluation in Chemical Education, Vol.70, No.9, 701-705, 1993.

[4] M. B. Nakhleh. Why some students don't learn chemistry: Chemical misconceptions, Journal of Chemical Education, 
Vol.69, No.3, 191-196, 1992.

[5] G. Sirhan. Learning difficulties in chemistry: An overview, Journal of Turkish Science Education, Vol.4, No.2, 4-20, 2007.

[6] R. Kozma, J. Russell. Students becoming chemists: Developing representational competence, Kluwer, England, 2005.

[7] V. C. Santos, A. Arroio. The representational levels: Influences and contributions to research in chemical education, Journal of Turkish Science Education, Vol.13, No.1, 3-18, 2016.

[8] D. L. Gabel. Improving teaching and learning through chemistry education research: A look to the future, Journal of Chemical Education, Vol.76, No.4, 548-554, 1999.

[9] J. K. Gilbert, D. F. Treagust. Introduction: Macro, submicro and symbolic representations and the relationship between them: Key models in chemical education, Springer, England, 2009.

[10] U. J. Enero, R. Umesh. Representations of chemistry phenomena in secondary school chemistry textbooks, Chemistry Education Research and Practice, Vol.20, No.1, 146-159, 2018.

[11] D. L. Gabel. Use of the particle nature of matter in developing conceptual understanding, Journal of Chemical Education, Vol.70, No.3, 193-194, 1993.

[12] N. Jansoon, R. K. Coll, E. Somsook. Understanding mental models of dilution in Thai students, International Journal of Environmental \& Science Education, Vol.4, No.2, 147-168, 2009.

[13] L. Grosslight, C. Unger, E. Jay, C. L. Smith. Understanding models and their use in science: Conceptions of middle and high school students and experts, Journal of Research in Science Teaching, Vol.28, No.9, 799-822, 1991.

[14] D. Gentner. Mental models, Psychology of, International Encyclopedia of the Social \& Behavioral Sciences, 9683-9687, 2001.

[15] P. N. Johnson-Laird. Mental models, Harvard University Press, England, 1983.

[16] T. L. Nahum, A. Hofstein, R. Mamlok-Naaman, Z. Bar-Dov. Can final examinations amplify students' misconceptions in chemistry? Chemistry Education Research and Practice, Vol.5, No.3, 301-325, 2004.

[17] G. M. Bodner, D. S. Domin. Mental models: The role of representations in problem solving in chemistry, Proceedings of University Chemistry Education, Vol.4, No.1, 24-30, 2000.

[18] Kaleci \& Korkmaz. STEM education research: Content analysis, Universal Journal of Education Research, Vol.6, No.11, 2404-2412, 2018.

[19] Duman \& İnel. Review of master's theses in the field of social studies education between 2008-2014, Universal Journal of Education Research, Vol.7, No.1, 66-73, 2019.

[20] R. Kozma, J. Russell. Multimedia and understanding: Expert and novice responses to different representations of chemistry phenomena, Journal of Research Science and
Teaching, Vol.34, 949-968, 1997.

[21] E. J. Park, G. Light, S. Swarat, D. Denise. Understanding learning progression in student conceptualization of atomic structure by variation theory for learning, Learning Progressions in Science (LeaPS) Conference, 2009.

[22] G. Sendur, M. Toprak, E. Pekmez. Analyzing of Students' Misconcep-tions about Chemical Equilibrium. International Conference on New Trends in Education and Their Implications, 2010.

[23] Chittleborough. Models and modeling in science education: multiple representation in chemical education. Thesis doctor, Curtin University, Australia, 2004.

[24] A. A. diSessa. Contextuality and coordination in conceptual change. Proceedings of the International School of Physics, 137-156, 2004.

[25] J. K. Gilbert, D. M. Watts. Concepts, misconceptions and alternative conceptions: Changing perspectives in science education, Studies in Science Education, Vol.10, 61-98, 1983.

[26] R. E. Mayer. Cognitive theory of multimedia learning, In The Cambridge handbook of multimedia learning. Cambridge University Press, USA, 2003.

[27] E-J. Park, A. L. White. The analysis of student models identified in interview responses as alternative models for learning atomic structure, In preparation, 2007.

[28] K. S. Taber. Misunderstanding the ionic bond, Education in Chemistry, Vol.31, 100-102, 1994.

[29] V. Talanquer. Commonsense chemistry: A model for understanding students' alternative conceptions, Journal of Chemical Education, Vol 83, No.5, 811-816, 2006.

[30] C. Y. Wang, L. H. Barrow. Characteristics and levels of sophistication: An analysis of chemistry students' ability to think with mental models, Research in Science Education, Vol.41, No.4, 561-586, 2011.

[31] J-W. Lin, M-H. Chiu, J-C. Liang. Exploring mental models and causes of students' misconceptions in acids and bases, National Taiwan Normal University, 1-12, 2004.

[32] E. J. Park, G. Light. Identifying atomic structure as a threshold concept: Student mental models and troublesomeness, International Journal of Science Education, Vol.31, No.2, 233-258, 2008.

[33] M. Calik, A. Kolomuc, Z. Karagolge. The effect of conceptual change pedagogy on students' conceptions of rate of reaction, Journal of Science Education and Technology, Vol.19, 422-433, 2010.

[34] M. Aydeniz, A. Pabuccu, P. S. Cetin, E. Kaya. Argumentation and students' conceptual understanding of properties and behaviors of gases, Journal of New Horizons In Education, Vol.10, 1303-1324, 2012.

[35] P. C. C. Mendonc, R. Justi. An instrument for analyzing arguments produced in modeling-based chemistry lessons, Journal of Research in Science Teaching, Vol.51, No.2, 192-218, 2013.

[36] S. M. Al-Balushi. Factors influencing pre-service science teachers' imagination at the microscopic level in chemistry, 
International Journal of Science and Mathematics Education, Vol.7, 1089-1110. 2009.

[37] M. Tuysuz, B. Ekiz, O. Bektas, E. Uzuntiryaki, A. Tarkin, E. S. Kutucu. Pre-service chemistry teachers' understanding of phase changes and dissolution at macroscopic, symbolic, and microscopic levels, Procedia Social and Behavioral Sciences, Vol.15, 452-455, 2011

[38] A. Hilton, K. Nichols. Representational classroom practices that contribute to students' conceptual and representational understanding of chemical bonding, International Journal of Science Education, Vol.33, No.16, 2215-2246, 2011.

[39] S. P. Madden, L. L. Jones, J. Rahm. The role of multiple representations in the understanding of ideal gas problems, Chemistry Education Research and Practice, Vol.12, 283-293, 2011

[40] A. Majid, B. K. Prahani. Analyze of students' learning outcomes based on mental, IOSR Journal of Research \& Method in Education, Vol.7, 120-124, 2017.

[41] S. Sarawan, C. Yuenyong. Thai students' mental model of chemical bonding, International Conference for Science Educators and Teachers, 1-7, 2017.

[42] O. T. Kırık, Y. Boz. Cooperative learning instruction for conceptual change in the concepts of chemical kinetics, Chemistry Education Research and Practice, Vol.13, 221-236, 2012.

[43] B. Venkataraman. Visualization and interactivity in the teaching of chemistry to science and non-science students, Chemistry Education Research and Practice, Vol.10, 62-69, 2009.

[44] C. Y. Wang, L. H. Barrow. Characteristics and levels of sophistication: an analysis of chemistry students' ability to think with mental, Research Science Education, Vol.41, 561-586, 2010.

[45] P. Meela, C. Yuenyong. The study of grade 7 mental model about properties of gas in science learning through model based inquiry, International Conference for Science Educators and Teachers, 1-6, 2018.

[46] R. Duschl, R. Grandy. Teaching scientific inquiry: Recommendations for research and implementation, Sense, Netherlands, 2008.

[47] J. Osborne, S. Erduran, S. Simon. Enhancing the quality of argument in school science, Journal of Research in Science Teaching, Vol.41, No.X, 994-1020, 2004.

[48] M. L. Head, K. Yoder, E. Genton, J. Sumperl. A quantitative method to determine preservice chemistry teachers' perceptions of chemical representations, Chemical Education Research and Practice, 1-18, 2017.

[49] M. M. W. Cheng, J. K. Gilbert. Modelling students' visualisation of chemical reaction, International Journal of Science Education, 1-24, 2017.

[50] J. H. Flavell. Metacognition and cognitive monitoring. American Psychologist, Vol.34, No.10, 906-911, 1979.

[51] M. C. Wang, G. D. Haertel, H. J. Walberg. What influences learning? A content analysis of review literature, Journal of Educational Research, Vol.84, No.1, 30-43, 1990.
[52] R. G. Yayla, G. Eyceyurt. Mental models of pre-service science teachers about basic concepts in chemistry. Western Anatolia Journal of Education Science, 285-294, 2010.

[53] A. Kolomuç, S. Tekin. Chemistry teachers' misconceptions concerning concept of chemical reaction rate, Eurasian Journal of Physics and Chemistry Education, Vol.3, No.2, 84-101, 2011.

[54] H. Tümay. Reconsidering learning difficulties and misconceptions in chemistry: Emergence in chemistry and its implications for chemical education, Chemistry Education Research and Practice, Vol.53, 1-15, 2016.

[55] A. K. Griffiths, K. R. Preston. An investigation of grade 12 students' misconceptions relating to fundamental characteristics of molecules and atoms, 1989.

[56] P. E. Blosser. What Research Says: Improving Science Education, School Science and Mathematics, Vol.86, No.7, 597-612, 1986

[57] S. L. Westbrook, E. A. Marek. A cross-age study of student understanding of the concept of homeostasis, Journal of Research in Science Teaching, Vol.29, No.1, 51-61, 1992.

[58] J. W. Renner, E. A. Marek. The learning cycle and elementary school science teaching. Heinemann Educational Inc., Portsmouth, 1988.

[59] J. I. Stepans. Developmental patterns in students' understanding of physics concepts, The psychology of learning science, 89-115, 1991.

[60] S. A. Kiray. The pre-service science teachers' mental models for concept of atoms and learning difficulties, International Journal of Education in Mathematics, Science and Technology, Vol.4, No.2, 147-162, 2016.

[61] A. Bergqvist, M. Drechsler, O. D. Jongb, S. C. Rundgren. Representations of chemical bonding models in school textbooks - help or hindrance for understanding? Chemistry Education Research and Practice, Vol.14, No.4, 589-606, 2013.

[62] N. Zarkadis, G. Papageorgiou, D. Stamovlasis. Studying the consistency between and within the student mental models for the atomic structure, Chemistry Education Research and Practice, Vol. 26, No.4, 893-902, 2017.

[63] B. H. Kwen. Consistency and inconsistency in A level students' understandings of a number of chemical reactions, Research in Science and Technological Education, Vol.14, No.1, 55-66, 1996.

[64] C. C. Clogg. Latent class models, Plenum, USA, 1995.

[65] C. M. Dayton. Latent class scaling analysis, Sage, California, 1998.

[66] J. Magidson, J. K. Vermunt. Latent class factor and cluster models, bi-plots and related graphical displays, Sociological Methodology, Vol.31, No.1, 223-264, 2001.

[67] K. S. Taber, R. Coll. Bonding, Kluwer Academic Publishers, Dordrecht, 2002.

[68] H. Özmen. The influence of computer-assisted instruction on students' conceptual understanding of chemical bonding and attitude toward chemistry: A case study for 
Turkey. Computers and Education, Vol.51, No.1, 423-438, 2008.

[69] R. Vladušić, A. B. Bucat, M. Ožić. Understanding ionic bonding - A scan across the Croatian education system, Chemistry Education Research and Practice, Vol.20, No.2, 1-14, 2013.

[70] G. Cakmakci. Students' understanding of the reaction rate and its relationships with the concentrations or pressure of reactants/products, The University of Leeds School of Education, England, 2005.

[71] Ö. Taştan, E. Yalçinkaya. Pre-service chemistry teachers' ideas about reaction mechanism, Journal of Turkish Science Education, Vol.7, No.1, 47-60, 2010.

[72] A. Wiyarsi, H. Sutrisno, E. Rohaeti. The effect of multiple representation approach on students' creative thinking skills: A case of 'Rate of Reaction' topic. International Conference on Research, Implementation and Education of Mathematics and Science, 1-9, 2018. 